\title{
Research on the Dilemma and Countermeasures of University Culture Construction under the Management Ethics Insight
}

\author{
He XIAO \\ College of Foreign Language \\ Neijiang Normal University \\ Neijiang, Sichuan \\ 1530100981@qq.com
}

\author{
Hong-yu XIE \\ College of Education and Sciences \\ Neijiang Normal University \\ Neijiang, Sichuan
}

\author{
Zhi-jun PANG \\ Poverty office of Xihua County \\ Zhoukou, Henan \\ 350080562@qq.com
}

\begin{abstract}
In the university management system, the culture construction is becoming an outstanding question along with the social development and university cultural development, this paper try to discover the dilemmas of university cultural construction and finally find out the corresponding countermeasures from four aspects, which are material culture; spiritual culture; regime culture and ecological culture respectively. The conclusion shows that the situation of university culture construction is not optimistic in China, which appeared the material culture is relatively drab absence in the university, spiritual culture, regime culture, ecological culture faced various problems, like the serious lack of university spirit culture; The mechanical system of regime culture; and the lost of ecological culture; it finally put forward the corresponding countermeasures. The innovation of this paper is that the countermeasures of university cultural construction are found under the management ethics insight. It provides a new reference and enlightenment for building the connotation of university culture construction under the perspective of management ethics.
\end{abstract}

Keywords-University Culture, Higher Education, Core Competitiveness, Management Ethics

In the process of college construction and development, culture is a big important strength to affect the behavior of organizations and members, cultural penetration in all aspects of the connotation of university construction. More and more people agree with cultural edification and nourish which is more conducive to the growth of the students. Some university administrators have also gradually paid great attention to shape university culture through the administrative ethics.

\section{Connotative MeAning OF University CUlture}

Domestic scholars defined conception of university culture from different angles and different levels, throughout the definition of university culture. This article mainly from the angle of management, analyzes the connotation of university culture in the following:

There are narrow and broad definitions for the University culture. The former point thinks university culture is a kind of social subculture, which is the university background on the basis of long-term practice accumulation and creation of culture, a microcosm of the excellent culture of long-term accumulation of human society, and is also an important part of human culture. The narrow point is a college culture referring to the unique spirit of a university. [1] University culture is an integral part of advanced ethical culture, a unique cultural perspective university and social development under the unique perspective, read and explain the relationship between the university and individual development, so the university culture construction and development is higher education researchers' unavoidable responsibility and mission in our country.

The university culture can be divided into material culture, system culture, spirit culture and ecological culture. Material culture is the material basis for the development of university; Spiritual culture is the soul and core of university culture; System culture is to promote coordinated development of material culture and spiritual culture at the university, and transformed into a harmonious and orderly and efficient operation of guarantee; Ecological culture is to coordinate the development among the university material culture, spiritual culture and institutional culture.

In sum, the so-called college culture refers to the sum total of material civilization, spiritual civilization, institutional civilization, and ecological civilization, which the advanced culture as the leading factor, the cultural activities between teachers and students as the main body, and the university spirit as background, by all the members of the university in the long-term process of running university. As a kind of objective existence, university culture is always accompanied with the 
development of university, which has an invisible internal force in the process of university development. The excellent university culture is the necessary condition to increase the efficiency of the university management; the people as the center of the university and school scale, the optimization of top priority to quality and promote one's personality; and which also is a Is open system for a variety of information exchange.

\section{CONNOTATIVE MEANING OF MANAGEMENT ETHICS}

There are more than dozens definition for management. Harold Hole and Heinz, Wee-rick defined management as: "the management is to design and maintain a good environment, make the person complete the goal efficiently in the group." And ethics usually "refers to a certain social basic interpersonal norms and the corresponding ethical principle." [2]

With the in-depth understanding of the management, people paid more attention to the ethical connotation increasingly. Some scholars achieve their consensus in the summarized successful experience of excellent enterprises in the world: when an enterprise is the most prosperous, it is the implementation of ethics in the management. [3]More and more people realize that cultural variables are the core of the management factors such as management ethics, and determine the success or failure of management. Based on the correspondence of management and ethics, some scholars of management ethics made the following definition: "the management ethics is the enterprise management in the treatment of internal and external human relations consciously abide by the moral code of conduct". [4]

The ethics notion has been noticed by university administrators in the university management. University is a special field of education, which has the major tasks to cultivate senior specialized talents, develop science and technology culture, and promote the modernization. However, the management ethics is a kind of value management in colleges and universities. It needs a kind of soft environment support, foil, edification, and disseminated. The contact of the soft environment is the university culture. The essence of the meaning and the highest value of university culture lies in the development of the members in colleges and universities, attaches great importance to the people, focuses on people, shapes people's humanistic orientation. The goal and the ultimate goal of management ethics in colleges and universities is the same. The core of University management ethics is the management of the college members' values of good and evil. The soul of culture in colleges and universities is a common belief in the values among members in colleges and universities, and both values are shared by each other. In the core values of university culture, ethics can became common ideals and beliefs of the group, and will directly affect the management of colleges and universities of ethical spirit. Therefore, in the process of university culture construction, it needs the manager continuously update concepts, change behavior in the long-term practice, through deep cultural psychology, the cultural mechanism into a conscious management consciousness and concept. [5] Apparently colleges' management ethics has become the deep structure of culture. In short, the university culture construction is to improve the quality of higher education, promote social harmony and progress, the necessary conditions for construction of higher education power in the management ethics.

\section{Dilemmas of University CUltural CONSTRUCTION}

At present, there is a widespread lack of ethical problems in our country, the problems of university culture from the Angle of management ethics shown in the following areas:

\section{A. The Drab of Material Culture}

In the process of university construction in the new period, there is a thought erroneous zone: purely pursuing big, extensive university development pattern. Especially in recent years, many provinces and cities has realized the merger of university, and to expand the scale of higher education in our country, many universities began to build the new campus, appeared more than one school district, even the so-called "college town". The construction of university innovation pursues beauty and big, ignoring the history of the university itself, the characteristics and the professional, scientific research and teaching. Even some universities built their own style and cultural symbols. They also could not reflect their own characteristics of school-running concept. Campus separation produced the culture construction on the space separation and separation, prevented cultural exchange and construction of university as a whole and it's hard to do real harmonious university culture construction.

\section{B. The Lack of Spirit Culture}

Today, every Country begins to advocate the spirit of university cultural construction activity, but still be affected by the influence of the era background and social environment. And in the construction of spiritual culture, scientific spirit won the supreme status, to cover the value of the humanities spirit, weakened the cultivation of humanistic spirit; Part pays too much attention to teachers and students substance and reality, but gives up the pursuit of lofty ideal, led to the university of some sort of "light" to weight, to make the university cultural drift in China. Many college students face the personal and social development goals, often tilt to the personal side, and pay attention to at present recent material interest, enthusiasm for more long-term belief, spiritual pursuit is obvious. A higher level of knowledge and low contrast to literacy, university spirit culture of utilitarianism and practical color is growing.

\section{The Mechanization of Regime Culture}

There are still some problems in the new period for regime culture: the participation level of system framers is too narrow; the democratic participation consciousness of teachers and students is not strong; and the transparency system of the formulation and implementation is not high. A small number of elite exercises the school management mode, everyone participates and management democracy has not been fully embodied; The imperfection of the rules and regulations of the student community construction, existing in the management of incentive mechanism is not flexible, corporate management lags behind, the conceptions of community backbone. 


\section{The Lost of Ecological Culture}

At present, some administrators who work in the first line understand the university culture is not very deep; the understanding on ecological culture connotation is not enough in the university, which cause its construction very difficult to be on the agenda. The vast majority of teachers in colleges and universities still adopt "cramming education", "cottage", and "line" teaching methods, emphasizing on classroom teaching, simply increasing course hours, making more and more students have to take the courses. Increasing pressure leads to the foundation of the curriculum is not solid, and caliber is not open. University cultural activities mainly focus on the entertainment culture in our country, taking the university cultural construction as a short-term behavior, an assault task to grasp. This is bound to make the university ecological culture construction lack of systematic and long-term perspective, weakening the role of culture in the process of university to complete their training objectives.

\section{COUNTERMEASURES OF UNIVERSITY CULTURAL CONSTRUCTION UNDER MANAGEMENT ETHICS INSIGHT}

It is an important part of University culture to cultivate university students, also is the important way to lead and shape students' ideological, moral, sentiment, value outside of the classroom. Good university culture has strong cohesion and attraction, which can regulate behavior and motivation of the staff and students' thought, cultivate and motivate the teachers and students' group consciousness and team spirit, promote the teachers and students' self-restraint, self-management and selfperfection, and maintain long-term stability and development of the school. To build university culture guided by the management ethics, it can try to begin from the following several aspects:

\section{A. Strengthen Material Culture}

University material culture is the material base for university development; it is an important symbol of comprehensive strength. To strengthen the construction of university physical culture is beneficial to promote the construction of university culture development and prosperity.

First of all, understand university material culture connotation. All the material objects through the senses can be felt is the university material culture, which belongs to hardware, and is to carry out the means of the spiritual culture and institutional culture. It is necessary material basis and prerequisite to promote the university culture construction. Second, pay attention to the practice of university material culture construction. Reasonable overall planning, build up the idea of sustainable development, scientific decision-making, especially on the adequacy of the rationality of the allocation of resources and use, from set out actually, play the role of people and objects; it should not only modern but also highlight the humanities connotation and the practice of famous colleges and universities is worthy of reference, because it has a long cultural history, and increases the humanistic spirit, especially the formation characteristics of colleges and universities, to show the characteristics and style of landscape management ethics.

\section{B. Attach Great Importance to Spirit Cultural}

As the core and soul of university culture, spirit culture embodied the university's personality and character, so in-depth study has important significance. First of all, understand the university spirit culture connotation. University spiritual culture is the integration and crystallization of cultural tradition, value system, the education idea and spiritual atmosphere. Once the spirit of university formed, it will be last and stable influence the thoughts and actions of the teachers and students in colleges and universities, and it has the characteristics of precipitation resistance, permeability and inheritance. Second, clear the goal of university spirit culture construction. The correct values are generally considered to be the core of university spirit culture, reflecting The Times; and to pursue, defend and stick to the truth should be the flag of university spirit culture construction; Stressing the cultivation of university spirit need long-term carefully nurtured, constantly enrich its connotation, once formed, it will fight against, strives for the development for the school inject strong fresh vitality from corrosion for the school to provide a strong backing, and at the same time, it will act a powerful guide, radiation function. Click the one hundred schools in our country, Peking University is famous for its "freedom of thought, inclusive"; Tsinghua University has the school motto of "unyielding, and hold world with virtue" and spread all over the world; Nankai University has the "allow fair can change" to cultivate a generation after generation of young talents; the three school of Peking University, Tsinghua university, Nankai university that Established in the Anti-Japanese War of the southwest adhering to the motto, to challenge the spirit of "resolute and adhere to the superior", created the brilliant history of Chinese higher education.

\section{Improve Regime Cultural}

Advanced university regime culture is to promote coordinated development of material culture and spiritual culture at the university, and transform into a harmonious and orderly and efficient operation of the guarantee. Therefore, improve the university regime cultural construction is an important content of university cultural construction in the new period.

Firstly, grasp the connotation of university regime system culture accurately. It is formed by the regulatory constraints, has to actions of guide and standardizes the university culture. Mainly includes: general system, refers the essential rules and regulations to maintain normal order at the university, such as teaching system, personnel system, etc.; Special system, that is the non-program system at the university, such as the students review the teacher system, summarizes the recognition system, etc.; University customs, refers to the established ceremony in the university for a long time, ceremony, etc., such as the university anniversary, graduation, etc.

Secondly, explore the countermeasures of regime cultural construction in the university. System of human nature advocated "people-oriented" concept, the rules and regulations the develop and implement in the university shall always maintain the lawful rights and interests of the staff and students, safeguarding the interests of the whole school and normal order, comply with national laws and regulations, conforms to the law 
of education development, guarantee the full of vigor and vitality; Any rules and regulations of scientific system must be based on science. It is also a process of scientific decision making, the system to reflect the basic rule of teaching and school practice, be scientific and reasonable and feasible.

\section{Pay Attention to Ecological Culture}

It is an important foundation of University ecological culture for university sustainable development, which also is a new dimension of university culture construction in China, and of which the construction shall be operated from the following aspects: First, set up the university ecological concept. Teachers and students should form the concept of the harmonious development between people and the environment, and should harmony the cultivation of people continue into the coexistence of ecological development, realize the unity of the dialectical development and environment. Second, set up the sustainable development of teaching ecological concept. In the process of teaching, it requires the teachers and students communicate with each other. So, compatibility, creative arts and interlinked, disciplines, build a natural, harmonious, open teaching and curriculum concept, recognize and respect the diversity of values between teachers and students, enhance the consciousness of the teachers and students of the future, to improve students' self-regulation and adaptability. Third, build a new university behavior system. The new university behavior system includes the social behavior, university behavior and individual behavior. Social behavior is to improve the ecological consciousness, formulate relevant laws, regulations and policies of ecological construction, improve the ecological evaluation system, and coordinate social green behavior. University behavior needs every college view their own reform and development with university behavior ecology, build a good ecological environment. Individual behavior is the entire teachers and students should be involved in the construction and maintenance of the University of Ecological Environment actively, according to their own special skill and the professional advantages to plan related ecological construction activity, combine work and study life, popularize ecological environment consciousness, advocate green behavior, and finally become green behavior model. Fourth, foster the sustainable ecological environment. Based on the ecological planning of construction group, it will form the spatial system of social development, which fully embodies the scientific and artistic. In the construction of university landscape, it should suggest the vegetation system is highly harmonious and unified, not only aesthetically pleasing appearance, the whole structure and internal should conform to the ecology principle and biological characteristics. Both of teachers and students should not only construct the ecological environment, but also promote the principles of natural evolution to establish the ecological civilization of the human and the nature coordinated evolution.

\section{CONCLUSION}

All in all, university culture is the soul of a university, and is also the spirit of a university. University culture not only reflects university development goals, educational philosophy, educational policy, professional characteristics and the spirit of humanity, but also mirrors a university group consciousness, values and behavior norms. It is a window to understand the social civilization, but also a growing point of social advanced culture. On the scale of higher education, China is a big country of higher education. But on the quality of education, China is far from the higher education power. In the rapid development of higher education, the university cultural construction has become a measure of the important condition of school competitiveness. Under the new situation, to strengthen the construction of university culture has become a school construction "double top priority". It provides a new reference and enlightenment for the university culture connotation of university culture construction under the perspective of Management ethics concept.

\section{REFERENCES}

[1] Xianzhang Hu. Research on the University Culture of Advanced Cultural Construction. [M]. Beijing: higher education press, 2009:117.

[2] France] fayol, chau on wah et al. Industrial management and general management [M]. Beijing: China social sciences press, 1982:22.

[3] Yiting Zhu. Small dictionary of Ethics [Z]. Shanghai: Shanghai dictionary press, 2004:29.

[4] [USA] Richard DE George honest competition in international business [M]. Shanghai: Shanghai academy of social sciences press, 2001:5.

[5] Yinchuan Zhang. Management ethics [M]. Hangzhou: zhejiang university press, 2006:5. 